\title{
Predictive Factors to Assess the Difficulty to Extract Retained Lower Third
}

Molars*

Factores predictivos para valorar la dificultad para extraer terceros molares inferiores

retenidos

Fatores preditivos para avaliar a dificuldade para extrair terceiros molares inferiores

retidos

Date of reception: 03-12-2019 | Date of acceptance: 27/04/2020

\author{
WiLliam ANDRÉS VARGas MAdRID \\ Universidad Central del Ecuador. Quito, Ecuador. \\ wianvama31@gmail.com; https://orcid.org/0000-0001-8165-488X
}

\author{
ANDREa MontSERRat GonZález Bustamante \\ Universidad Central del Ecuador. Quito, Ecuador. \\ dra.mgonzalezb@gmail.com; https://orcid.org/0000-0001-5832-3898
}

Paola Elizabeth Zurita Minango

Universidad Central del Ecuador. Quito, Ecuador.

ely_4_1@ hotmail.com; https://orcid.org/0000-0002-2059-8527 
*Original research.

Correspondence: wianvama31@gmail.com; dra.mgonzalezb@gmail.com;

ely_4_1@ @hotmail.com

doi: https://doi.org/10.11144/Javeriana.uo39.pfad

How to cite: Vargas Madrid WA, González Bustamante AM, Zurita Minango PE. Predictive factors to assess the difficulty to extract retained lower third molars. Univ Odontol. 2020; 39. https://doi.org/10.11144/Javeriana.uo39.pfad

\section{ABSTRACT}

Background: Third molar eruption occurs in a very limited space. Several difficulty scales have been used to determine the complexity when extracting retained molars, which are key for surgical planning and prediction. A scale including indicators such as quality of mucosa and bone, as well as shape and number of roots is introduced. Purpose: Evaluate the difficulty in extracting retained lower third molars, using the scale proposed by Romero-Ruiz, and thus estimate the presence of intraoperative complications and surgical time. Methods: An observational descriptive crosssectional study was carried out, with a sample of 100 extractions of retained lower third molars in patients between 16 and 40 years of age. The following variables were evaluated: spatial relationship, depth, relationship with mandible ramus/space, integrity of bone and mucosa, roots, dental follicle, and surgical time. The data were summarized in absolute frequency tables and 
analyzed with Pearson's $\mathrm{Chi}^{2}$ test $(\mathrm{p}<0.05)$. Results: $71 \%$ of third molars were classified as "difficult" on the scale. There were significant differences in terms of surgical time-age $(\mathrm{p}=$ 0.002), presence of complications-location of the third molar $(\mathrm{p}=0.015)$, presence of complications-follicle size $(\mathrm{p}=0.022)$, difficulty-sex $(\mathrm{p}=0.011)$, difficulty-age $(\mathrm{p}=0.068)$.

Conclusions: This scale can be used to plan extraction treatments for retained lower third molars to reduce surgical times and anticipate complications.

\section{Keywords}

dental follicle; dentistry; intraoperative complications; impacted tooth; oral diagnostics; oral surgery; retained tooth; risk assessment scale; surgical time; third molar; treatment planning

\section{RESUMEN}

Antecedentes: La erupción del tercer molar sucede en un espacio muy limitado. Se han empleado diferentes escalas de dificultad para determinar la complejidad al extraer molares retenidos, son clave para la planeación y predicción quirúrgicas. Se presenta un escala que incluye indicadores como calidad de mucosa y hueso, así como forma y número de raíces. Objetivo: Evaluar la dificultad para extraer terceros molares inferiores retenidos, al usar la escala propuesta por Romero-Ruíz, y así estimar la presencia de complicaciones transoperatorias y el tiempo quirúrgico. Métodos: Se realizó un estudio observacional descriptivo de corte transversal, con una muestra de 100 extracciones de terceros molares inferiores retenidos en pacientes entre 16 y 40 años. Se evaluaron las variables: relación espacial, profundidad, relación con la rama/espacio, integridad 
de hueso y mucosa, raíces, folículo dental y el tiempo quirúrgico. Los datos se resumieron en tablas de frecuencias absolutas y se analizaron con la prueba $\mathrm{Chi}^{2}$ de Pearson $(\mathrm{p} \leq 0,05)$. Resultados: 71 $\%$ de terceros molares se clasificaron como "difíciles" en la escala. Hubo diferencias significativas en cuanto a tiempo quirúrgico-edad $(\mathrm{p}=0,002)$, presencia de complicaciones-localización del tercer molar $(p=0,015)$, presencia de complicaciones-tamaño del folículo $(p=0,022)$, dificultadsexo $(p=0,011)$, dificultad-edad $(p=0,068)$. Conclusiones: Esta escala se puede usar para planear tratamientos de extracción de terceros molares inferiores retenidos para disminuir tiempos quirúrgicos y prever complicaciones.

\section{Palabras clave}

cirugía bucal; cirugía oral; complicaciones intraoperatorias; diagnóstico bucal; diente retenido; escala de valoración de riesgo; folículo dental; odontología; planeación del tratamiento; tercer molar; tiempo quirúrgico

\section{RESUMO}

Antecedentes: A erupção do terceiro molar ocorre em um espaço muito limitado. Várias escalas de dificuldade foram usadas para determinar a complexidade na extração de molares retidos, que são fundamentais para o planejamento cirúrgico e a previsão. É introduzida uma escala incluindo indicadores como qualidade da mucosa e osso, bem como forma e número de raízes. Objetivo: Avaliar a dificuldade de extração de terceiros molares inferiores retidos, utilizando a escala proposta por Romero-Ruíz, e assim estimar a presença de complicações intra-operatórias e tempo 
cirúrgico. Métodos: Foi realizado um estudo observacional descritivo transversal, com amostra de 100 extrações de terceiros molares inferiores retidos em pacientes entre 16 e 40 anos. As seguintes variáveis foram avaliadas: relação espacial, profundidade, relação com o ramo/espaço da mandíbula, integridade óssea e mucosa, raízes, folículo dentário e tempo cirúrgico. Os dados foram resumidos em tabelas de frequência absoluta e analisados com o teste $\mathrm{Chi}^{2}$ de Pearson $(\mathrm{p}<0,05)$. Resultados: $71 \%$ dos terceiros molares foram classificados como "difíceis" na escala. Houve diferenças significativas em termos de tempo cirúrgico-idade $(\mathrm{p}=0,002)$, presença de complicações-localização do terceiro molar $(\mathrm{p}=0,015)$, presença de complicações-tamanho do folículo $(p=0,022)$, dificuldade-sexo $(p=0,011)$, dificuldade-idade $(p=0,068)$. Conclusões: Esta escala pode ser usada para planejar tratamentos de extração para terceiros molares inferiores retidos para reduzir o tempo cirúrgico e antecipar complicações.

\section{Palavras-chave}

cirurgia oral; complicações intraoperatórias; dente retido; diagnóstico oral; escala de avaliação de risco; folículo dentário; odontologia; planejamento de tratamento; tempo cirúrgico; terceiro molar

\section{INTRODUCTION}

Third molars, teeth that for the most part do not erupt through a normal process, cause various complications, including pericoronitis, periodontitis, cavities, root resorption of adjacent dental organs, cystic pathologies, occlusal disharmony, crowding of teeth, and TMJ dysfunctions, these mainly due to its anomalous position (1-4). The causes of retention or impaction are associated 
with a decrease in chewing activity, either due to the evolution of having fewer teeth in the mouth or due to the soft nature of the food $(5,6)$. The conference of the National Institute of Agreements for Development held in 1979 reached a consensus that the management of these impactions is the extraction of the third molars (5). However, due to the proximity to important anatomical structures such as the adjacent second molar, the vascular-nerve bundle that passes through the lower dental canal, the anterior border of the ascending ramus, and the internal and external bony cortices $(3,7)$, these teeth present different degrees of difficulty and various intraoperative complications that include damage to the inferior dental, lingual, and long buccal nerves (paresthesia), hemorrhage, severe trismus, fracture of adjacent teeth, and even mandibular fracture $(3,6-10)$.

Given this background, it is necessary to perform pre-surgical extraction studies (11-15) in relation to predictive factors of difficulty such as those used in Pederson, Peñarrocha, and Koerner scales (9-11,16-17). In this work, the use of the Romero-Ruiz clinical-radiographic scale (17), which has been used by various authors especially in Latin America (11,18-19) and has shown its applicability worldwide. This scale, by gathering a large number of clinical radiographic variables, allows for better surgical planning to avoid possible complications inherent to surgery. It is also carried out through a simple mathematical calculation (adding the values obtained and dividing them by two) that is useful in daily practice. Due to the aforementioned, the present study aimed to assess the difficulty to extract retained lower third molars using the Romero-Ruiz scale and to determine the different intraoperative complications and the surgical time used.

\section{MATERIALS AND METHODS}


This descriptive study with an observational and cross-sectional design was approved by the Bioethics Committee of the Centro Clínico Quirúrgico Ambulatorio Hospital del Día Central Quito (CCQA-HDCQ) of the Ecuadorian Institute of Social Security and the Subcommittee of Research Ethics in Human Beings from the Central University of Ecuador, whose sample was nonprobabilistic and selected for convenience. The study subjects were patients who attended the Oral Surgery service of the CCQA-HDCQ for third molar extractions, whose ages ranged from 16 to 40 years of age $(9,20)$. The sample size was obtained based on two articles by Burgos et al. (11) and Ribes et al. (14) with a total of 100 extractions of retained lower third molars. Patients with systemic involvement, who attended without radiography, and who did not agree to participate in the study, were excluded.

To apply the scale, panoramic radiographs were used as they are the diagnostic test used in this health care service. Prior to data collection and analysis, all operators were standardized by videoconference with Dr. Manuel María Romero Ruiz (17), author of the clinical-radiographic scale to assess the difficulty in extracting third molars (Table 1). After standardization, several measurements were performed on a significant sample of patients until equal results were obtained between operators. In addition, it was decided to use vegetable/based paper, which allowed to eliminate the observation bias in the equipment. 
TABLE 1

MODIFICATION OF THE DIFFICULTY ASSESSMENT SCALE FOR THE EXTRACTION OF THIRD-PARTY MOLARS BY ROMERORUIZ (17)

\begin{tabular}{|c|c|c|}
\hline Variable & Indicators & Values \\
\hline Spatial relationship & $\begin{array}{ll}\text { - } & \text { Mesioangular } \\
\text { - } & \text { Horizontal/transversal } \\
\text { - } & \text { Dertical } \\
\text { Distoangular }\end{array}$ & $\begin{array}{l}1 \\
2 \\
3 \\
4\end{array}$ \\
\hline Depth & $\begin{array}{ll}\text { - } & \text { Level A } \\
\text { - } & \text { Level B } \\
\text { - } & \text { Level C }\end{array}$ & $\begin{array}{l}1 \\
2 \\
3\end{array}$ \\
\hline $\begin{array}{l}\text { Relationship to } \\
\text { ramus/available } \\
\text { space }\end{array}$ & $\begin{array}{ll}- & \text { Class I } \\
- & \text { Class II } \\
- & \text { Class III }\end{array}$ & $\begin{array}{l}1 \\
2 \\
3\end{array}$ \\
\hline $\begin{array}{l}\text { Bone and mucosa } \\
\text { integrity }\end{array}$ & $\begin{array}{l}\text { - Partially covered by mucosa } \\
\text { - Partially covered by bone and mucosa } \\
\text { - Fully covered by mucosa, but not by bone } \\
\text { - Covered by mucosa and partially by bone } \\
\text { - Fully covered by mucosa and bone }\end{array}$ & $\begin{array}{l}1 \\
2 \\
3 \\
4 \\
5\end{array}$ \\
\hline Roots & $\begin{array}{l}\text { - } \quad \text { More than } 2 / 3 \text { fused } \\
\text { - } \quad \text { More than } 2 / 3 \text { separated or less than } 1 / 3 \text { fused } \\
\text { More than } 2 / 3 \text {, multiple }\end{array}$ & $\begin{array}{l}1 \\
2 \\
3\end{array}$ \\
\hline Follicle size & $\begin{array}{ll}-\quad+1 \mathrm{~mm} \\
-\quad 0-1 \mathrm{~mm}\end{array}$ & $\begin{array}{l}1 \\
2\end{array}$ \\
\hline $\begin{array}{l}\text { Difficulty index } \\
\text { (sum divided by } \\
\text { two) }\end{array}$ & $\begin{array}{ll}\text { - } & \text { Very difficult } \\
\text { - } & \text { Difficult } \\
\text { - } & \text { Little difficult }\end{array}$ & $\begin{array}{c}8-10 \\
5-7 \\
3-4\end{array}$ \\
\hline
\end{tabular}

For the procedure, after obtaining a signed informed consent for participation in the study by the patient, the radiographic images of the third molar, second molar, and ascending ramus of the mandible corresponding to each side were transported to the vegetable paper with a $2 \mathrm{~b}$ pencil. This was done with the help of a X-ray viewer for printed X-rays, and the same computer in the case of digital X-rays. After copied the image of the panoramic radiograph, the procedure carried out was: To obtain Winter's spatial relationship $(21,22)$, two perpendicular lines were drawn (the first the major axis of the third molar and the second the long axis of the second molar). Once these lines were drawn, we proceeded to observe what type of angle was formed to determine if the third molar was in a mesioangular, horizontal, vertical, or distoangular position (Figure 1). 
FIGURE 1

WINTER'S SPACE RELATIONSHIP DETERMINATION DIAGRAM

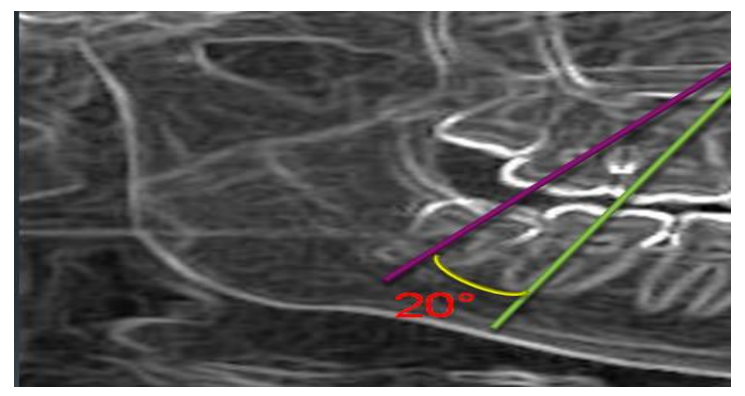

To obtain the third molar depth proposed by Peel \& Gregory $(22,23)$, three horizontal lines were drawn. The first covered the highest part of the third molar; the second represented the occlusal aspect of the second molar; and the third was the cervical line of the second molar. Thus, the relationship of the third molar with the occlusal plane of the second molar was obtained (Figure 2).

FIGURE 2

PEEL \& GREGORY'S DEPTH AND RELATIONSHIP WITH ASCENDING RAMUS DIAGRAM

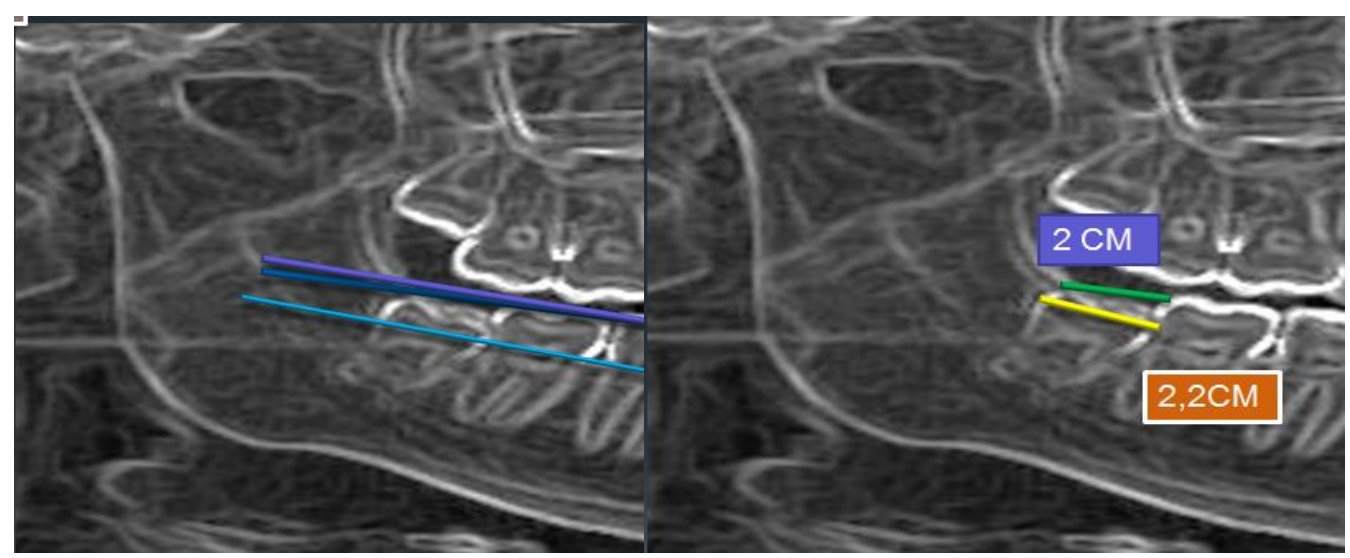

To obtain the relationship of the third molar with the mandible ascending ramus proposed by Peel \& Gregory $(22,23)$, the mesiodistal width of the retained third molar was measured with a ruler in millimeters. In addition, the space between the distal aspect of the second adjacent molar and the 
anterior border of the mandible ascending ramus was measured with the same millimeter ruler. In this way, the eruption space of the third molar was obtained (Figure 2).

To assess the integrity of bone and mucosa, both radiographic and clinical analyses were performed. By inspection, it was observed whether or not the tooth was covered by bone or mucosa (11). For the analysis of root morphology, a radiographic inspection was also carried out in which the presence of fusions, separations, or multiplicity of the roots of the retained lower third molar was observed $(14,24)$. For the size of the follicular sac, the radiolucent space on the crown of the tooth was measured with a millimeter ruler (14,25). Likewise, the letters D and I were placed on the vegetable paper to determine if the third molar was located on the right (D) or left (I) (Figure 3).

FIGURE 3

ROOT, TOOTH FOLLICLE SIZE, BONE INTEGRITY, AND LOCALIZATION OF THIRD MOLAR DIAGRAM

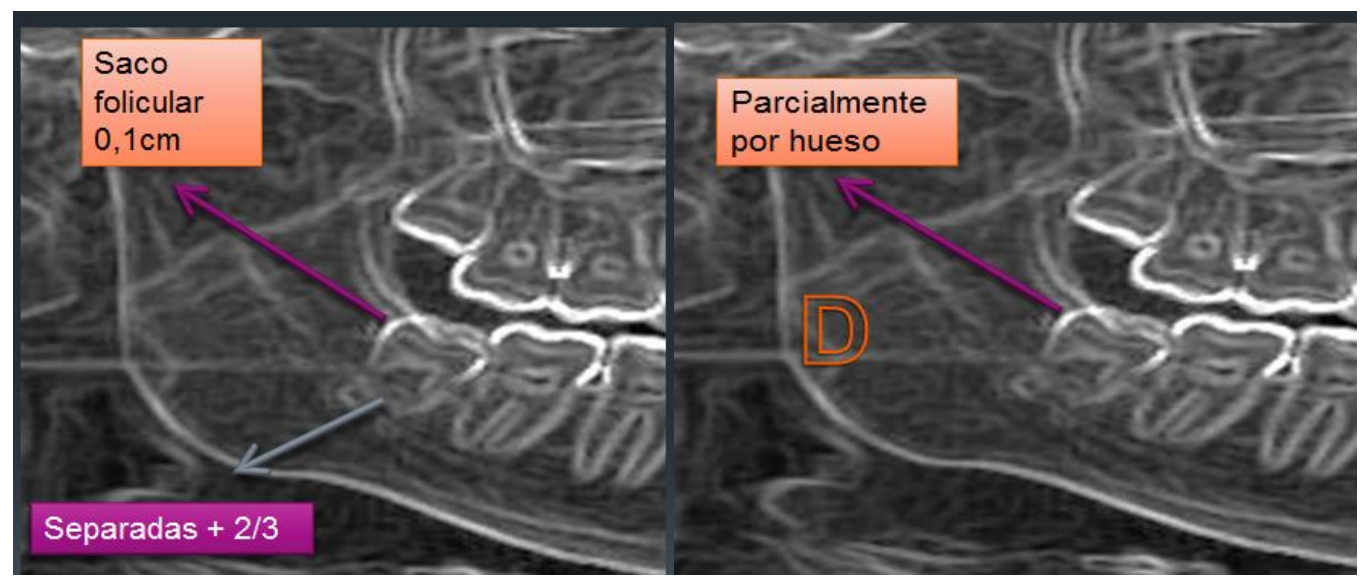

Captions: Follicle sac (saco folicular); Separated $+2 / 3$ (separadas $+2 / 3$ ); Partially by bone (parcialmente por hueso)

Data were registered in a double-entry spreadsheet and the difficulty scale was obtained. To do this, all the values (excluding sex, age, time and complications) were added and divided by two. Difficulty ranges were assigned as follows: 3-4 = "little difficult;" 5-7 = "difficult;" 8-10 = "very difficult” $(11,17)$. 


\section{Surgical Phase}

Once the mandibular truncal local anesthesia was verified, we proceeded as follows:

1. With a \# 3 handle and \# 15 blade scalpel (one blade for each tooth to be extracted), a linear incision was made around the dental necks.

2. The mucoperiosteal flap was lifted using a Minnesota periosteal and retractor.

3. An osteotomy was performed with a low speed air rotor handpiece, a \# 8 tungsten carbide bur (one bur for each tooth to be extracted) and abundant irrigation with $9 \%$ sodium chloride.

4. A dental section was performed with the same rotary instruments and, with the help of a straight elevator, the extraction was performed.

5. The pocket was curetted with a sharp spoon and copious irrigation.

6. It was sutured with 3-0 Vicryl and an atraumatic needle (5).

Any complications that arose during the operative procedure were recorded. The time spent by the operator between the incision and the suture was also recorded.

Data were transferred to the SPSS ${ }^{\circ}$ version 22 program through which the statistical analysis was performed. The data analysis included descriptive statistics for the unique variables and, Pearson's Chi2 test was used to determine the association between variables $(\mathrm{p}=0.05)(22)$.

\section{RESULTS}


Of the 100 third molars extracted, regarding gender, $57 \%$ were of females and $43 \%$ belonged to males. $10 \%$ of the third molars had a difficulty prediction of "slightly difficult," $71 \%$ were classified as "difficult," and $19 \%$ as "very difficult." In $32 \%$ of the cases, the operation took 510 minutes to complete, while in $44 \%$ the surgical time ranged from 10.01 minutes to 15 minutes (this time interval being the most frequent one). The operation took between 15 and 60 minutes in $24 \%$ of cases and the procedures required the use of additional instruments (apical elevators).

Among patients aged 16-20 years, the most frequent surgical time (50\%) was 5-10 minutes. In ages 21 to 30 years, the most frequent surgical time was 10.01-15 minutes. In the 31-to-40-year age group the most common surgical time was $10.01-15$ minutes $(\mathrm{p}=0.002)$. Similarly, at ages 16 to 20 , the difficulty scale tended to be "difficult" (28.9\%). Among 31-to-40 year-olds, the scale tended to be "very difficult" $(23.5 \%)$. This suggests that the older the patient, the more difficult it would be to perform the extraction and, therefore, longer surgical time would be required $(\mathrm{p}=$ 0.002) (Table 2).

TABLE 2

CHI-SQUARE TEST

\begin{tabular}{lccc}
\hline Variables compared & Value & df & $\begin{array}{c}\text { Statistical asymptotic } \\
\text { significance (2-sided) }\end{array}$ \\
\hline Surgical time-age & 16.773 & 4 & 0.002 \\
Presence of complications-third molar & 5.892 & 1 & 0.015 \\
localization & 5.222 & 1 & 0.022 \\
Presence of complications-follicle size & 9.006 & 2 & 0.011 \\
Difficulty scale-sex & & & \\
\hline
\end{tabular}

Of the 6 complications reported, all occurred on the left side (quadrant III), which represents 11.5 $\%$ of the total $(\mathrm{p}=0.015)$. The same cases had a follicular size of $0.0 \mathrm{~mm}$, which represents 10.9 $\%(\mathrm{p}=0.022)$. All complications were anticipated, since in the clinical-radiographic assessment 
they were classified as "very difficult," and the necessary instruments were on hand to resolve them (Table 2).

The male sex in $86 \%$ of the cases was classified as "difficult" on the scale, which contrasts with the female sex in which the classifications were "not very difficult" (15.8 \%) and "very difficult" $(24.6 \%)(\mathrm{p}=0.011)$. This suggests that male sex is also related to the difficulty of extraction (Table 2).

\section{DISCUSSION}

Third molar surgery is one of the treatments most performed by dentists in daily practice $(5,6,11,21)$. Therefore, various authors agree that this type of surgery should be carried out by qualified professionals, should be evaluated prior upon execution, in order to experience minimal pre-, intra-, and post-operative complications $(11,14,18,26,27)$. This has generated the need to evaluate scales that allow predicting the difficulty that a third molar extraction may have due to the proximity to important anatomical structures $(9,10)$.

In this study, the Romero-Ruiz clinical-radiographic scale (17) was used and variables such as location, surgical time, sex, age, and presence of complications were added. Data were obtained from panoramic radiographs that, despite not being the gold standard, as argued by various authors (28-30), are the most widely used diagnostic method in the Latin American community and especially in the public sector of Ecuador. In this sense, Alvira and Juodbalyz $(9,31)$ consider that the economic component is a very important factor in the use and prescription of diagnostic 
methods. For this reason, cone beam radiography is limited and is only used in very complex cases or in which clear anatomical elements such as the roots or the mandibular canal are not found (3134). These variables, when compared with the panoramic study, are the only ones that presented statistical significance $(\mathrm{p} \leq 0.002)(30-32-34)$. This validates the present finding, since other variables were used for the analysis of difficulty, which provides more diagnostic elements.

Shital et al. (4), Ribes et al. (14), Artola et al. (35), Fernández (36), Santosh-Kumar \& Aysha (37) and Olguín-Martínez \& Amarillas-Escobar (24), like in this study, agree that the females (57\%) undergo more frequently retained lower third molar extractions. It is also observed that sex and difficulty $(\mathrm{p}=0.011)$ have an important surgical relationship. $11.6 \%$ presented a scale of "very difficult" in males and $24.6 \%$ in females. The "difficult" value was more present in males ( $86 \%)$, findings that coincide with those of Bachmann et al. (7) and Fernández-Sainz (36). In the present study, it was expected to find a high percentage of "not very difficult" evaluations among females. That was not the case. One of the possible reasons that supported this presumption was based on the gender-related bone composition differences (38).

Fernández-Sainz (36), Díaz-Encomendero (18), González (12) and Ryalat (22) coincide with this study's findings in that age and time are statistically significant variables in third molar surgeries, in which the older the patient, the longer the surgical time $(\mathrm{p}=0.002)$. Perhaps, this is due to the fact that the cancellous bone presents greater compaction at an older age (22).

Alvira (31), Díaz (18), Burgos (11), Fernández (36) and González-Barboza \& Simancas-Pereira (12) observed that the most frequent surgical time was 10-20 minutes, findings that are similar to 
those of the present study. All of them were classified as "difficult." Even so, on a scale of "very difficult," the results vary from author to author. This may be due to the clinician's expertise, which is perhaps a variable not assessed in many studies and that should be taken into account in future research.

Bachmann et al. (7) found a significant difference between the presence of complications and the third molar location. Quadrant III presented greater complications and longer surgical time. Similarly, this work found a close relationship between these two variables $(p=0.015)$, since 6 out of 6 complications were on the left side. Alvira-González et al. (31), Guzmán et al. (39) and Quinatoa (40) attribute the presence of complications on the left side to poor visibility of the operator and not being the operating side of the dominant hand, which will possibly translate into postoperative complications.

Villafuerte (25) observed that the size of the follicular sac is $0.25 \mathrm{~mm}$, in such a way that, the smaller this follicle, the more complicated the extraction will be due to the risk of ankylosis, which entails a higher frequency of complications. Thus, in this study, 6 of the complications occurred in teeth that had a follicular size of 0 . The comparison of these two variables was statistically significant $(\mathrm{p}=0.022)$.

Finally, Ribes et al. (14), Yasser-Kharma et al. (26), Díaz-Encomendero (18) and Burgos et al. (11) agree with this research in that the difficulty prediction in the vast majority of extractions is "difficult" (71\%). In addition, all these authors along with others such as Shital, Santosh Juodzbalis, Yuasa, Burgos, Ribes and even Peel and Gregory, conclude that the difficulty 
prediction with scales described in the literature is very important to pre-surgically assess the extraction of retained lower third molars. This reduces surgical time and improves planning for possible complications $(4,6,9-11,14,23)$.

\section{CONCLUSION}

The use of the clinical-radiographic scale by Romero Ruiz and his team, to which other variables such as age, sex, and third molar location were added, allowed predicting and planning surgical treatment and reducing/avoiding complications and reducing the surgical time, without the need to resort to more complex diagnostic methods.

\section{RECOMMENDATIONS}

Include in the analysis other variables to predict difficulty such as coronal area, length, type and curvature of the roots, Winter's distance, thickness of the basal bone, relationship with mandibular canal, experience and expertise of the operator, anxiety, and mouth opening.

Use this scale of difficulty together with a visual analogue scale to, in this way, contrast the difficulty that each clinician suggests.

Complete a more contextualized scale based on the needs of the Latin American population, including variables such as socioeconomic status. 
Perform analysis with imaging means that use new technologies such as the cone beam.

\section{REFERENCES}

1. Del Puerto M, Casas-Insua L, Cañete- Villafranca R. Terceros molares retenidos, su comportamiento en Cuba. Revisión de la literatura. Rev Med Electron. 2014; 36 (1): 752-762.

2. Vergara AD, Llinás HJ, Bustillo JM. Lower anterior third molar impact on dental crowding. A new approach. Int J Odontostomatol. 2017; 11(3): 327-332. http://doi.org/10.4067/S0718$\underline{381 X 2017000300327}$

3. Vázquez DJ, Subiran BT, Osende NH, Estévez A, Vautier ME, Hecht P. Estudio comparativo de la relación de los terceros molares inferiores retenidos con el conducto dentario inferior en radiografías panorámicas. Rev Cient Odontol. 2016 Jul; 12(2): 14-18.

4. Shital P, Saloni M, Farzan S, Taksh S; Impacted mandibular third molars: a retrospective study of 1198 cases to assess indications for surgical removal, and correlation with age, sex and type of impaction — a single institutional experience. J Maxillofac Oral Surg. 2017 Jan-Mar; 16(1): 79-84. http://doi.org/10.1007/s12663-016-0929-z

5. Gay Escoda C, Peñarrocha M, Sanchéz MA, Figueiredo R, Romero-Ruíz M Sanchéz- Torres A, Camps- Font O. Diagnóstico e indicaciones para la extracción de los terceros molares: extracción de los terceros molares. 1ª ed. España: Sociedad Española de Cirugía Bucal; 2018.

6. Santosh P. Impacted mandibular third molars: review of literature and a proposal of a combined clinical and radiological classification. Ann Med Health Sci Res. 2015 Aug; 5(4): 229-234. http://doi.org/10.4103/2141-9248.160177 
7. Bachmann H, Cáceres R, Muñoz C, Uribe S. Complicaciones en cirugías de terceros molares entre los años 2007 y 2010, en un hospital urbano, Chile. Int J Odontostomat. 2014; 8(1): 107112. http://doi.org/10.4067/S0718-381X2014000100014

8. Buesa JM. Implicaciones electromiográficas en la cirugía del tercer molar inferior (trabajo de grado). Madrid, España. Universidad Complutense de Madrid; 2015.

9. Juodzbalys G, Daugela P. Mandibular third molar impaction: review of literature and a proposal of a classification. J Oral Maxillofac Res. 2013 Apr-Jun; 4(2): 1-12. http://doi.org/10.5037/jomr.2013.4201

10. Yuasa H, Kawai T, Sugiura M. Classification of surgical difficulty in extracting impacted third molars. Br J Oral Maxillofac Surg. 2002; 40(1): 26-31. http://doi.org/10.1054/bjom.2001.0684

11. Burgos G, Morales E, Rodríguez O, Aragón J, Sánchez M. Evaluación de algunos factores predictivos de dificultad en la extracción de los terceros molares inferiores retenidos. Mediciego. 2017; 23(1): 8-15.

12. González-Barboza S, Simancas-Pereira Y. Clasificaciones Winter y Pell-Gregory predictoras del trismo postexodoncia de terceros molares inferiores incluidos. Rev Venez Invest Odontol IADR. 2017; 5(1): 57-75.

13. Mezzour M, El Harti K, El Wady W. Predicting third molar removal difficulty: radiological assessment. Acta Scientif Dental Sci. 2017 Nov; 1(6): 13-19.

14. Ribes N, Sanchis JC, Peñarrocha D, Sanchis JM. Importance of a preoperative radiographic scale for evaluating surgical difficulty of impacted mandibular third molar extraction. J Oral Sci Rehabil. 2017; 3(1): 52-59.

15. Hyam DM. The contemporary management of third molars. Aust Dent J. 2018; 63(1): 19-26. http://doi.org/10.1111/adj.12587 
16. Koerner KR. The removal of impacted third molars-principles and procedures. Dent Clin North Am. 1994; 38(2): 255-278.

17. Romero M, Gutiérrez J, Torres D. El tercer Molar Incluido. 1ª ed. Madrid, España: GSK; 2012.

18. Díaz-Encomendero C. Relación entre el grado de dificultad y el tiempo efectivo en la exodoncia de terceros molares inferiores (trabajo de grado). Trujillo, Perú: Universidad Privada Antenor Orrego; 2015.

19. Lozano-Coquinche M. Evaluación preoperatoria del grado de dificultad quirúrgica para la exodoncia del tercer molar mandibular incluido en pacientes atendidos en la clínica odontológica de la Facultad de Odontología UNAP (trabajo de grado). Iquitos, Perú: Universidad Nacional de la Amazonia Peruana; 2010.

20. Kautto A, Vehkalahti MM, Ventä I. Age of patient at the extraction of the third molar. Int J Oral Maxillofac Surg. 2018; 47(7): 947-951. http://doi.org/10.1016/j.ijom.2018.03.020

21. Winter GB. Principles of exodontia as applied to the impacted third molar: a complete treatise on the operative technic with clinical diagnoses and radiographic interpretations. St. Louis, MO: American Medical Book; 1926.

22. Ryalat S, Al-Ryalat SA, Kassob Z, Hassona Y, Al-Shayyab M. Impaction of lower third molars and their association with age: radiological perspectives. BMC Oral Health. 2018 Apr; 18(58): 1-5. http://doi.org/10.1186/s12903-018-0519-1

23. Peel GJ, Gregory GT. Impacted mandibular third molars: classification and modified technique for removal. Dental Digest. 1933 Sep; 39(9): 330-338.

24. Olguín-Martínez T, Amarillas-Escobar E. Morfología radicular de los terceros molares. Root canal morphology of third molars. Rev ADM. 2017; 74 (1): 17-24. 
25. Villafuerte L. cambios histopatológicos de los folículos dentales en relación a los espacios pericoronarios y posición de los terceros molares no erupcionados, en el centro médico naval “CM ST”, en el año 2014-2015 (trabajo de grado) Lima, Perú. Universidad Mayor de San Marcos; 2015.

26. Yasser-Kharma M, Sakka S, Aws G, Tarakji B, Zakaria-Nassani M. Reliability of Pederson scale in surgical extraction of impacted lower third molars: proposal of new scale. J Oral Dis. 2014; (1): 1-4. http://doi.org/10.1155/2014/157523.

27. Al-Samman A. Evaluation of Kharma scale as a predictor of lower third molar extraction difficulty. Med Oral Patol Oral Cir Bucal. 2017 Nov; 22 (6): 796-799. http://doi.org/10.4317/medoral.22082.

28. Gu L, Zhu C, Chen K, Liu X, Tang Z. Anatomic study of the position of the mandibular canal and corresponding mandibular third molar on cone-beam computed tomography images. Surg Radiol Anat. 2018 Oct; 40(6): 609-614. http://doi.org/10.1007/s00276-017-1928-6.

29. Haghanifar S, Moudi E, Yaghoobi S, Bijani A, Ghasemi N. Evaluation of the anatomical relationship between the mandibular canal and roots of third molars using cone-beam computed tomography (CBCT). J Babol Univ Med. 2016 Mar; 18(3): 7-13.

30. De Toledo G, Peralta-Mamani M, De Fatima A, Fischer CM, Marques H, Fischer IR. Influence of cone beam computed tomography versus panoramic radiography on the surgical technique of third molar removal: a systematic review. Int J Oral Maxillofac Surg. 2019; 48: 1340-1347. http://doi.org/10.1016/j.ijom.2019.04.003

31. Alvira-González J, Figueiredo R, Valmaseda-Castellón E, Quesada-Gómez C, Gay-Escoda C. Predictive factors of difficulty in lower third molar extraction: A prospective cohort study. 
Med Oral Patol Oral Cir Bucal. 2017 Jan; 22 (1): 108-114. http://doi.org/10.4317/medoral.21348

32. Freire BB, Nascimento EHL, Vasconcelos KF, Freitas DQ, Haiter-Neto F. Radiologic assessment of mandibular third molars: an ex vivo comparative study of panoramic radiography, extraoral bitewing radiography, and cone beam computed tomography. Oral Surg Oral Med Oral Pathol Oral Radiol. 2019; 128(2): 166-175. http://doi.org/10.1016/j.0000.2018.11.002

33. Ghaeminia H, Meijer GJ, Soehardi A, Borstlap WA, Mulder J, Berge SJ. Position of the impacted third molar in relation to the mandibular canal. Diagnostic accuracy of cone beam computed tomography compared with panoramic radiography. Int J Oral Maxillofac Surg. 2009; 38: 964-971. http://doi.org/10.1016/j.ijom.2009.06.007

34. Neves FS, Souza TC, Almeida SM, Haiter-Neto F, Freitas DQ, Bóscolo FN. Correlation of panoramic radiography and cone beam CT findings in the assessment of the relationship between impacted mandibular third molars and the mandibular canal. Dentomaxillofac Radiol. 2012 Oct; 41(7): 553-557.

35. Artola- Tapia M, Gutiérrez- Artola K, Reyes- Bellorín E. Efectividad del kin gingival como alternativa al uso de antimicrobianos en pacientes sometidos a cirugía de terceros molares en las clínicas UNAN-Managua, durante el segundo semestre 2015 (trabajo de grado). Managua, Nicaragua. Universidad Nacional Autónoma de Nicaragua; 2016.

36. Fernández- Sainz B. Estudio de la relación entre la dificultad quirúrgica en la exodoncia del tercer molar y las variables clínicas y séricas (trabajo de grado) Valencia, España. Universitat de Valencia; 2017. 
37. Santhosh- Kumar MP, Aysha S. Angulations Of Impacted Mandibular Third Molar: A Radiographic Study in Saveetha Dental College. J. Pharm. Sci. \& Res. 2015; 7(11): 981-983.

38. Ishwarkumar S, Pillay P, Degama BZ, Satyapal KS. An osteometric evaluation of the mandibular condyle in a black KwaZulu-Natal population. Int J Morphol. 2016; 34(3): 848853.

39. Guzmán-Castillo G, Paltas-Miranda M, Benenaula- Bojorque J. Núñez-Barragán K, SimbañaGarcía D. Cicatrización de tejido óseo y gingival en cirugías de terceros molares inferiores. Estudio comparativo entre el uso de FIbrina rica en plaquetas versus cicatrización Fisiológica. Rev Odontol Mex. 2017; 21 (2): 114-120. http://doi.org/10.1016/j.rodmex.2017.05.007

40. Quinatoa C. Accidentes y complicaciones transquirúrgicos de terceros dermatológico Gonzalo González durante el período 2014 (trabajo de grado).Quito, Ecuador. Universidad Central del Ecuador; 2015. 